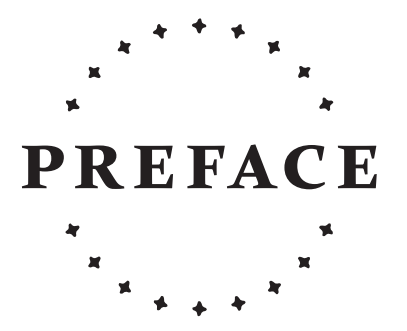

The historic town of Cranbury is situated near major highways in the rich farmland of southern Middlesex County in central New Jersey. It is one of the oldest towns in the state, with the first recorded settlement by English colonists in 1697 and evidence of Indian sites there long before that. For more than three hundred years, the forces emanating from transit routes and fertile farmland have shaped Cranbury, whose history is both unique and representative of developments in New Jersey and the nation. The town's story is also a hopeful one of citizen activism on behalf of the historic preservation of the village and its adjoining farmland.

Unlike many old, rural towns that became transformed through suburbanization in the twentieth century, Cranbury retained its picturesque, small-town image and much of its rural character. It was also innovative in linking historic preservation of the village with the maintenance of adjoining farmsteads. How this has come about-how Cranbury preserved much of its nineteenth-century character while accommodating twentieth-century forces of economic growth-provides one of the most important themes of this book. Cranbury, which has preserved the best of the past while astutely meeting the challenges of the present, provides an inspiration for active, intelligent civic participation and a model for enlightened development.

Main Street in Cranbury still resembles the America of a Norman Rockwell painting. Arriving through farmers' fields on rural, two-lane roads or a nearby highway, visitors discover a tree-shaded village of white, clapboard houses from the eighteenth and nineteenth centuries, most with dark wooden shutters, many with front porches and some with white picket fences. In I723, Benjamin Franklin, then a seventeenyear-old printer's apprentice from Boston, walked through Cranbury 


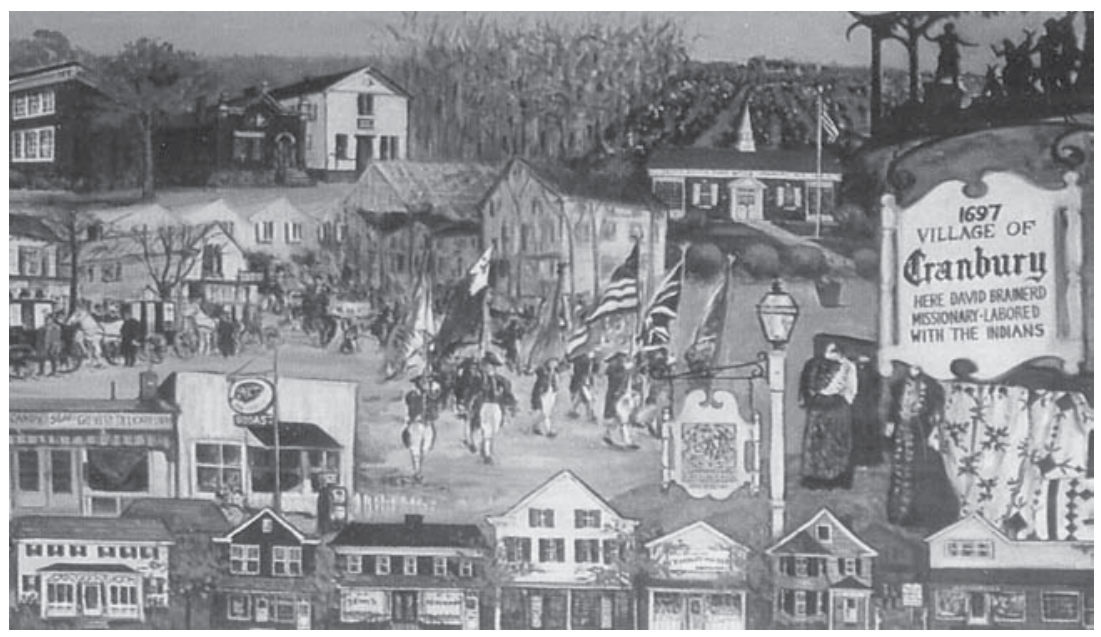

FIG. 1. A portion of the Mural of Historic Cranbury, painting by Lee Stang Harr, 1983. The full mural is on display in the post office in Cranbury. (Courtesy of the Cranbury Historical and Preservation Society)

on his way to becoming an editor and newspaper publisher in Philadelphia. Currently at the entrance to the town, a small, hanging sign depicts the famous, young Presbyterian missionary David Brainerd addressing the Indians under a great elm tree here in 1745 . Later, the organizer of American Methodism, Bishop Francis Asbury, preached several times in Cranbury between 1772 and 1790 .

Main Street today is a mix of houses and small, locally owned stores and restaurants, one or two stories high, most of them built in the nineteenth century. Uphill from the lake, dam, and old mill site sits a former tavern and inn, the Cranbury Inn, now a restaurant and bar, which traces its origins back to the late i70os. Nearby stands the First Presbyterian Church, established in Cranbury in 1740 . Farther along are more old houses, including one on the site of an earlier home where, during the Revolutionary War, the Marquis de Lafayette and Colonel Alexander Hamilton stayed and General George Washington made his headquarters on the way to the Battle of Monmouth in 1778 . Two decades later, Vice President Aaron Burr changed horse and carriage in Cranbury on his flight south as a result of his lethal duel with Hamilton. In the twenty-first century, much of the quaint hamlet with its surrounding farms seems like the mythical Brigadoon, a place where time stands still. 
The fact that Cranbury remained "the best preserved igth century village in Middlesex County," as stated in the successful 1979 application for including the town on the state and national historic registers, and one of the best in the state, helped assure its addition to those two registers. A small, rural village still bordered, at least on its west side, by a vista of largely undisturbed farmland and old farmsteads, Cranbury embodies the hopes and aspirations of the nation back in the mid-nineteenth century. As the application explained, "Optimism, faith, and reasoned growth are part of what Cranbury represented and continues to represent. It is this assemblage of buildings-historically and architecturally - which makes Cranbury an attractive entity unique from any other contemporary villages. It is this identity which sets Cranbury apart from its nearby surroundings of look-alike suburbs and modern commercial developments creating a significant historical village."

Yet, in recent years, this charming, picturesque town, nestled within the open farmland that comprises much of its thirteen and a half square miles, has been confronted with the wave of development that seems

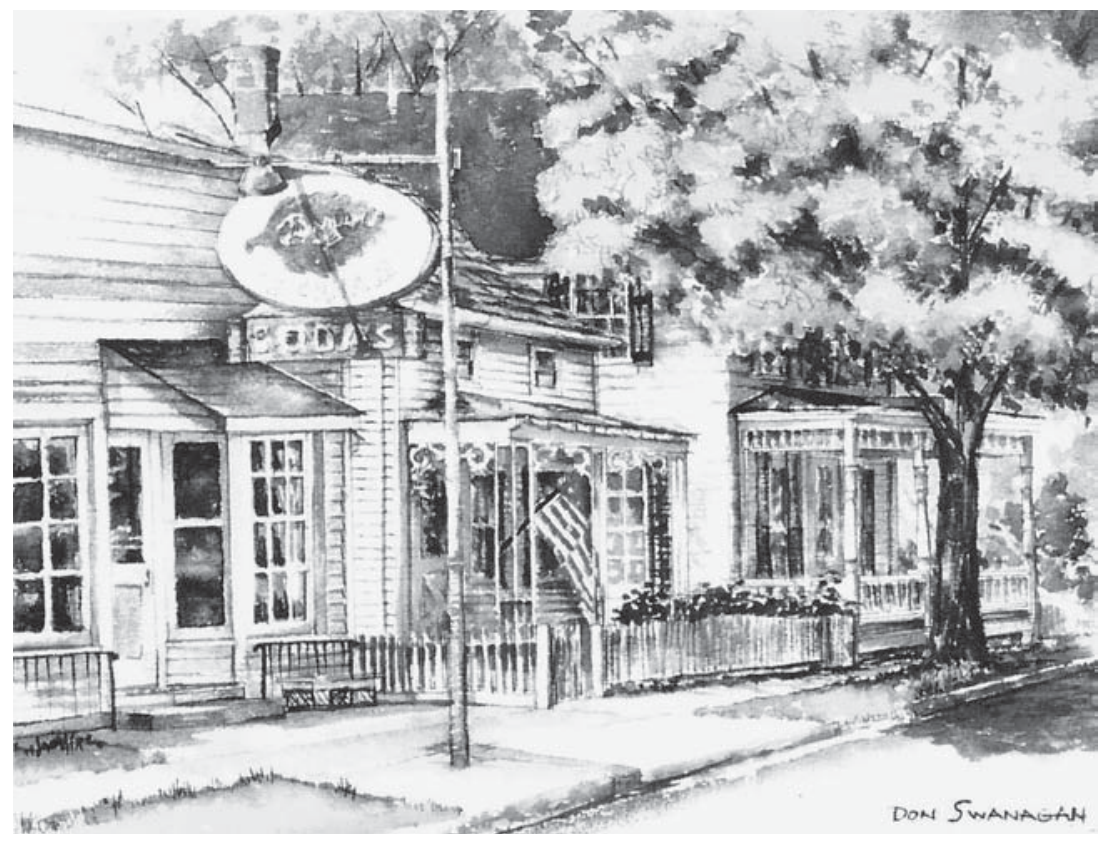

FIG. 2. "Harold O'Neil's Store," on North Main Street, Cranbury. Watercolor painting by Don Jo Swanagan, 1982. (Courtesy of Virginia H. Swanagan) 
to be relentlessly pushing suburban subdivisions and businesses into the farmlands of New Jersey. Running through the eastern side of the township are U.S. Route 130 and the New Jersey Turnpike, the latter one of the most heavily traveled roadways in America. Half a dozen miles to the west lies Princeton's booming Route I corridor with its office parks, malls, and corporate campuses. Despite its location, the village has remained a historic treasure. Its residents have banded together to preserve the charmingly quaint village and the farmland that helped sustain it for more than three centuries. Part of the town's significance as a historic rural village is the result of its relatively undisturbed relationship with old farms and farmsteads. While accepting gradual and carefully controlled growth and development, the residents of Cranbury have been able to keep the village, much of its farmland, and most of the roads that lead to and through it, free, for the most part, from massive, look-alike subdivisions and the clutter of billboards, gas stations, auto dealers, franchise eateries, and strip malls that are so often a part of suburban sprawl.

With its active involvement since the I970s in preserving its historic village and subsequently its historic farmland, Cranbury has been at the cutting edge of the historic preservation movement in America. That movement began its most dynamic growth with the passage of the $\mathrm{Na}$ tional Historic Preservation Act in 1966 to identify and protect cultural properties of local, state, and national historical significance. Cranbury's Historic District, with its more than two hundred buildings, was added to the New Jersey Register of Historic Places in 1979 and to the National Register of Historic Places in 1980. Subsequently recognizing the intrinsic, historic connection between the rural village and its farmland, the town, in the decades around its tercentennial in 1997, preserved nearly three thousand agricultural acres, nearly two-thirds of its qualified farmland.

Consequently, Cranbury's story is not only about the course of New Jersey and American history but also about preserving the best of the past and applying it to enhance the quality of life in the present. A number of planners and conservationists have seen it as a model, applicable to other towns as well. Cranbury has used its past as well as the expertise, techniques, and resources of the present to avoid much of the sameness of appearance that afflicts so many modern communities. In its successes, it has built upon that history to create a sense of connectedness 
and to encourage and utilize a civic-mindedness that has enabled the community to face the challenges of the present and the future.

Its historic character provides Cranbury with a unique sense of place, but, like its stately oak trees, the town's history is rooted in the development of New Jersey and America. It is a story from the past, both distant and recent, that offers us a model and a hope for the future. 



\section{CRANB URY}


